\title{
Coexistence of Mucous Retention Cyst and Basal Cell Adenoma Arising from the Lining Epithelium of the Cyst
}

\section{Report of Two Cases}

\author{
D. Antoniades ${ }^{\mathrm{a}} \quad$ A. Epivatianos ${ }^{\mathrm{a}} \quad$ A. Markopoulos ${ }^{\mathrm{a}} \quad$ A. Kolokotronis ${ }^{\mathrm{a}}$ \\ T. Zaraboukas ${ }^{b}$ \\ Departments of a Oral Medicine and Oral Pathology and ${ }^{b}$ Histopathology, University of Thessaloniki, \\ Thessaloniki, Greece
}

\section{Key Words}

Mucous retention cyst $\cdot$ Basal cell adenoma $\cdot$ Salivary gland tumors $\cdot$ Salivary gland cysts

\begin{abstract}
Objective: To report 2 cases of coexisting mucous retention cyst and basal cell adenoma arising from the lining epithelium of the cyst. Clinical Presentation and Intervention: Two cases of painless swellings, well-demarcated, soft to palpation, and located in the submucosa of the upper lip were clinically examined with the provisional diagnosis of mucocele or salivary gland tumor. Histological examination showed the presence of a large unilocular cystic cavity in many parts surrounded by single or bilayered lining epithelium composed of flattened to cuboidal cells, and in other parts surrounded by projections of cells arranged in a trabecular pattern far into the cystic cavity. The trabeculae were composed of basal and low columnar cells that sometimes formed small duct-like structures. Immunohistochemistry showed that the lining epithelium of the cystic cavity and the cells of the projections expressed cytokeratin 7 and high-molecular-weight cytokeratins. The cells of the projections were weakly positive for S-100 protein and negative for
\end{abstract}

vimentin and $\alpha$-smooth muscle actin. Based on the results, a diagnosis of coexisting mucous retention cysts and basal cell adenomas arising from the lining epithelium of cysts was made. Conclusion: The coexistence of mucous retention cysts and basal cell adenomas arising from the lining epithelium of the cyst is reported. Copyright $\odot 2009$ S. Karger AG, Basel

\section{Introduction}

Salivary gland cysts represent about 6-9\% of all salivarygland diseases [1]. The development of salivary gland tumors in preexisting salivary gland cysts is extremely rare. Research of the literature disclosed only 5 cases [14], in which no case of a mucous retention cyst with the development of basal cell adenoma has been presented. Furthermore, the formation of a mucous retention cyst secondary to the presence of basal cell adenoma in the lining epithelium of the cyst, to the best of our knowledge, has not been reported.

We report 2 cases of the coexistence of a mucous retention cyst and basal cell adenoma arising from the lining epithelium of the cyst.

\section{KARGER}

Fax +41613061234 E-Mail karger@karger.ch www.karger.com
(C) 2009 S. Karger AG, Basel

1011-7571/09/0183-0248\$26.00/0

Accessible online at:

www.karger.com/mpp
A. Epivatianos

Department of Oral Medicine and Pathology, Dental School

University of Thessaloniki

GR-54124 Thessaloniki (Greece)

Tel. +30 2310999 521, Fax +30 2310999 455, E-Mail aepivati@dent.auth.gr 


\section{Case Reports}

Case 1

A 68-year-old man was referred to the Department of Oral Medicine and Oral Pathology, Dental School of the University of Thessaloniki, in October 2002 because of a painless swelling that periodically fluctuated in size. Intraoral examination revealed a well-demarcated mass, soft to palpation, measuring $1.5 \times 1 \mathrm{~cm}$, and located in the submucosa of the upper lip. The covered mucosa was reddish-blue in color. The patient's dental and medical histories were unremarkable. The provisional clinical diagnosis was mucocele or salivary gland tumor. Excisional biopsy was carried out under local anesthesia. The wound was closed primarily, and the healing was uneventful. Follow-ups at regular intervals during past 5 years have disclosed no recurrence or metastasis.

\section{Case 2}

A 67-year-old man was also referred to the Department of Oral Medicine and Oral Pathology, Dental School of the University of Thessaloniki, in March 2007 because of a painless swelling in the upper lip. Intraoral examination revealed a well-demarcated mass, measuring $0.5 \times 0.5 \mathrm{~cm}$, soft to palpation, and located in the submucosa of the upper lip. The covered mucosa was normal in color. The patient's dental and medical histories were unremarkable. The clinical provisional diagnosis was salivary gland tumor or mucocele. Excisional biopsy was performed under local anesthesia. The wound was closed primarily, and the healing process was uneventful. The patient was asymptomatic 10 months postoperatively.

Serial sections of $4 \mu \mathrm{m}$ thickness cut from the 2 specimens were fixed in $10 \%$ formalin and embedded in paraffin. Sections were stained with $\mathrm{HE}$ and periodic acid-Schiff (PAS) reagent after diastase digestion. Immunohistochemistry was performed for the detection of vimentin (Dakocytomation, Glostrup, Denmark; V9, dilution 1:100), $\alpha$-smooth muscle actin ( $\alpha$-SMA) (Dakocytomation; 1A4, dilution 1:100), high-molecular-weight cytokeratins (Dakocytomation; 34bE12, dilution 1:20), S-100 protein (Biocare, Concord, Calif., USA; DR96 + BC96, dilution 1:500), cytokeratin 7 (Biocare; Ks 20.8, dilution 1:80), and epithelial membrane antigen (Novocastra, Newcastle-upon-Tyne, UK; NCL-L-EMA, dilution 1:80) using the streptavidin-biotin-peroxidase method and the Ventana autostainer (Ventana Medical Systems, Tuscon, Ariz., USA). The sections were mounted on poly-L-lysine-coated slides, dewaxed, and dehydrated. Endogenous peroxidase activity was quenched with $3 \%$ peroxide in methanol for $10 \mathrm{~min}$ at room temperature. Antigen retrieval was performed for 5 antigens (table 1). After rinsing the sections with phosphate-buffered saline (PBS), further blocking was accomplished utilizing normal goat serum at 1:20 dilution for $20 \mathrm{~min}$ at room temperature. Then, after being washed with PBS, the sections were incubated with the monoclonal primary antibodies for $32 \mathrm{~min}$, whereas sections incubated in PBS were used as a negative control. After being washed with PBS, the slides were incubated with biotinylated goat anti-mouse prediluted secondary antibodies for $20 \mathrm{~min}$, washed with PBS, and developed by diaminobenzidine reaction. Mayer's hematoxylin was used as the counterstain.

Examination of sections of case 1 stained with HE showed the presence of a large unilocular cystic cavity in many parts surrounded by a single or bilayered lining epithelium composed of flattened to cuboidal cells, and in other parts surrounded by pro-
Table 1. Pretreatment for antigen retrieval

\begin{tabular}{ll}
\hline Antibody & Pretreatment \\
\hline Vimentin & $\begin{array}{l}\text { microwave; citrate buffer } 0.01 \mathrm{M} ; \\
\mathrm{pH} 7.2 ; 95^{\circ} \mathrm{C} ; 15 \mathrm{~min}\end{array}$ \\
\hline$\alpha$-SMA & no treatment \\
\hline $\begin{array}{l}\text { High-molecular-weight } \\
\text { cytokeratins }\end{array}$ & $\begin{array}{l}\text { protease I in } 0.05 \mathrm{M} \text { phosphate buffer; } \\
\mathrm{pH} 7.8 ; 38^{\circ} \mathrm{C} ; 8 \text { min }\end{array}$ \\
\hline $\begin{array}{l}\text { S-100 protein } \\
\text { microwave; citrate buffer } 0.01 \mathrm{M} ; \\
\text { pH 7.2; } 95^{\circ} \mathrm{C} ; 15 \text { min }\end{array}$ \\
\hline $\begin{array}{l}\text { Cytokeratin } 7 \\
\text { Epithelial membrane }\end{array}$ & $\begin{array}{l}\text { microwave; citrate buffer } 0.01 \mathrm{M} ; \\
\text { antigen }\end{array}$ \\
\hline
\end{tabular}

Protease I purchased from Sigma, St. Louis, Mo., USA.

jections of cells arranged in a trabecular pattern far into the cystic cavity (fig. 1a). The trabecular pattern was composed of basal and low columnar cells that sometimes formed small duct-like structures (fig. 1b). Some luminal cells of duct-like structures contained PAS-positive granules. Thin-walled blood vessels and hyaline were present between the interconnecting cords of tumor cells (fig. 1c). Mitotic figures and cellular atypia were absent. The lining epithelium of the cystic cavity was surrounded by dense collagen without inflammatory infiltration. The space of the cystic cavity contained erythrocytes, some polymorphonuclear leukocytes and occasionally macrophages. Adjacent to the large cystic cavity, several labial salivary glands were present. Some of them had atrophic lobules and chronic inflammatory infiltrate (fig. 1a). Immunohistochemically, the lining epithelium of the cystic cavity and the tumor cells of the projections expressed cytokeratin 7 and high-molecular-weight cytokeratins (1, 5, 10, 14; fig. 1d, 2a). The tumor cells were focally and weakly stained for S-100 protein and were negative for vimentin, an $\alpha$-SMA (fig. 2c). The border of lumens of duct-like structures was stained for epithelial membrane antigen.

Sections stained with HE for case 2 showed the presence of a large cystic cavity, in most parts surrounded by a single or bilayered lining epithelium composed of flattened to cuboidal cells. In one region, a large projection far into the cystic cavity composed of basal and low columnar cells arranged in a trabecular pattern was present (fig. 2b). These cells occasionally formed duct-like structures. In some areas, focal palisading of tumor cells was observed. Between the interconnecting cords of tumor cells, hyaline and small blood vessels with a hyalinized wall were present (fig. 2d). Mitotic figures and cellular atypia were not seen. Several labial salivary glands were adjacent to the cystic cavity (fig. 2b). Some lobules of these glands were moderately atrophic. Occasionally, luminal cells of duct-like structures contained PAS-positive granules. The immunohistochemical findings were similar to those seen in case 1 . Based on the histological and immunohistochemical findings, a diagnosis of mucous retention cyst and basal cell adenoma arising from the lining epithelium of the cyst was made. 
Fig. 1. Case 1. a Large cystic cavity lined by flattened or cuboidal cells with projections of tumor cells into cystic space. HE. Bar = $100 \mu \mathrm{m}$. b Part of a projection is composed of basal and low columnar cells that occasionally form small duct-like structures (arrows). HE. Bar $=30 \mu \mathrm{m}$. c Luminal cells contain small granules positive for PAS after diastase digestion (arrowheads). Depositions of hyaline (arrows). Bar $=30 \mu \mathrm{m}$. d The lining epithelium of the cystic cavity (arrow) and most of tumor cells express cytokeratin 7. Streptavidin-biotin-peroxidase method. Bar $=80 \mu \mathrm{m}$.
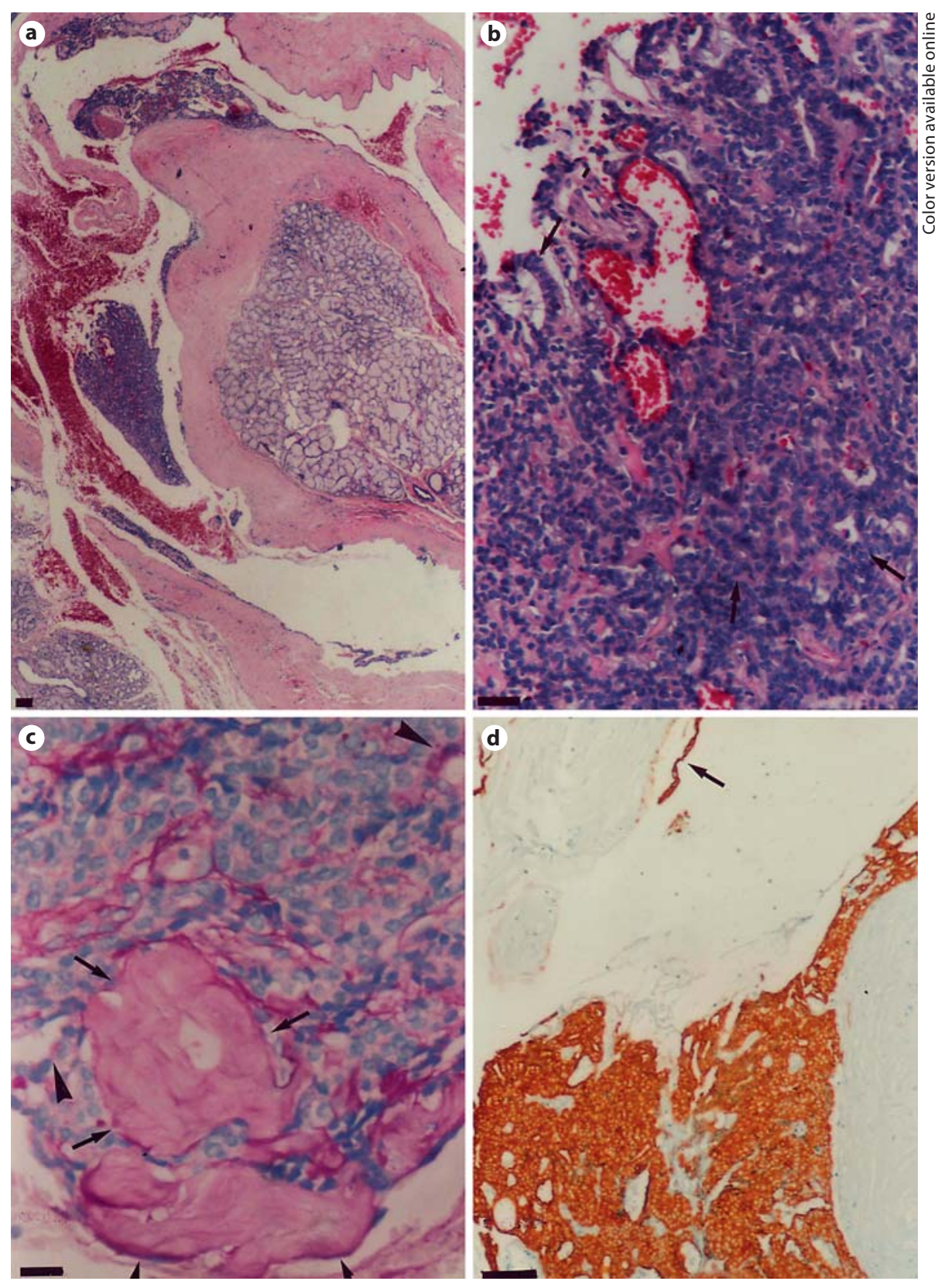

\section{Discussion}

Mucous retention cyst is an uncommon cyst that occurs in parotid and minor salivary glands. In the oral cavity, the mucous retention cyst occurs almost equally in all regions, and partial obstructions of the ducts are considered as the important factor in its development [5]. The lining epithelium consists of flattened duct cells similar to intercalated duct cells or of bilayered duct cells similar to striated and excretory ductal cells. In some ar- eas, plump papillary projections are developed. Occasionally, goblet cells and nonkeratinized squamous epithelium may be present within the epithelial lining of the cyst [1]. Our cases fulfill the histological criteria for diagnosis of mucous retention cysts. In our cases, goblet cells, nonkeratinized squamous epithelium, and papillary projections lined by cuboidal to columnar cells forming a multi-cystic appearance were not observed, and therefore mucoepidermoid carcinoma and papillary cystadenoma were excluded from the differential diagnosis. 
Fig. 2. Case 1 (a, c). a Luminal (arrowheads) and abluminal tumor cells (arrows) express high-molecular-weight cytokeratins. Streptavidin-biotin-peroxidase method. Bar $=40 \mu \mathrm{m}$. c Luminal (arrow) and abluminal cells (arrowhead) are positive for S-100 protein. Streptavidin-biotin-peroxidase method. Bar $=20 \mu \mathrm{m}$. Case 2 (b, d). b Large cystic cavity lined by flattened or cuboidal cells, and one projection far into the cystic space. Labial salivary gland (arrow). HE. Bar $=100 \mu \mathrm{m}$. d Part of the projection where a small duct-like structure (high arrow), focal palisading of tumor cells (small arrows) and hyaline (arrowheads) are present. HE. Bar $=40 \mu \mathrm{m}$.
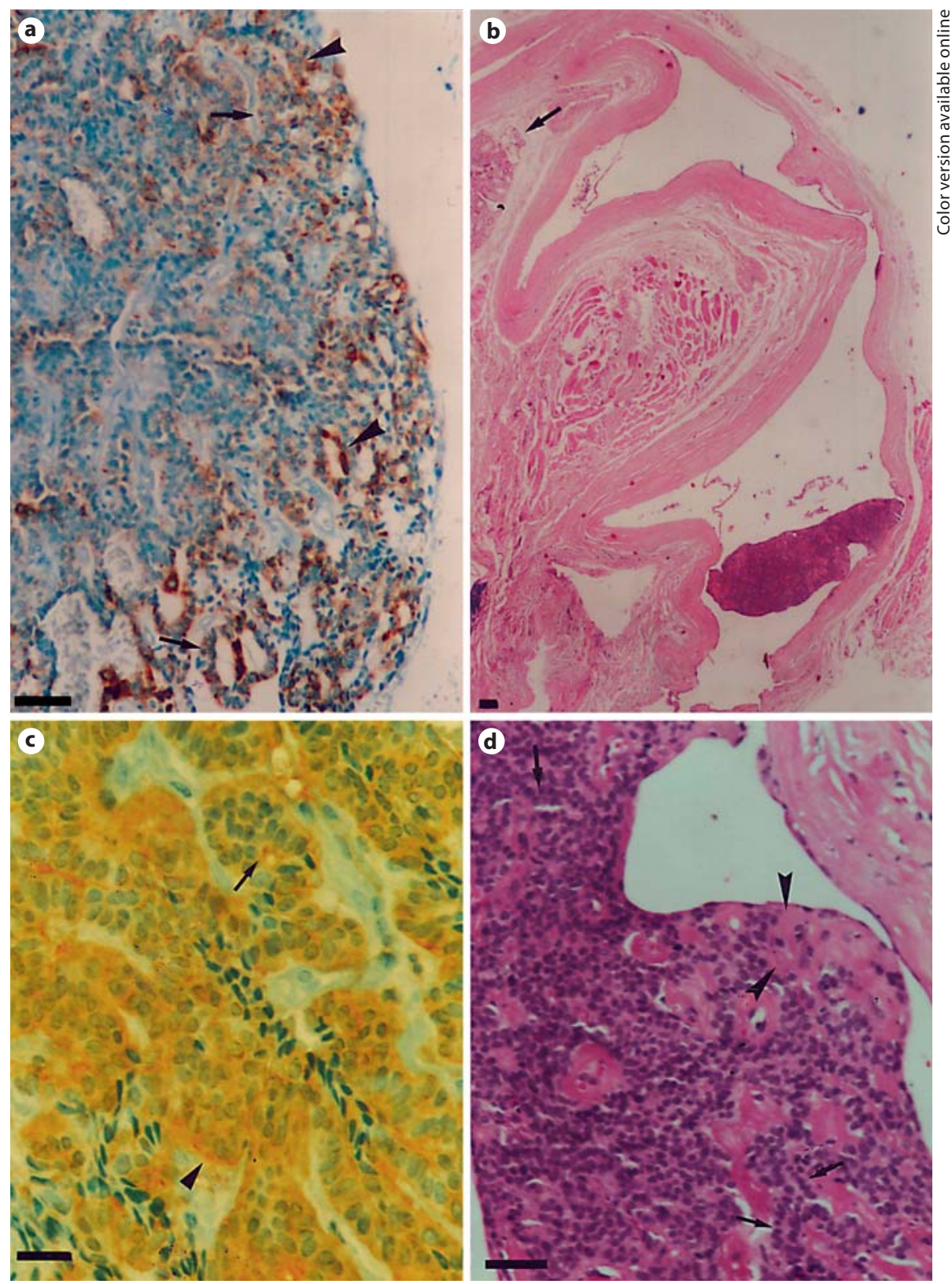

Basal cell adenoma accounts for about 1 to $2 \%$ of salivary gland tumors and, in the oral cavity, the upper lip is the most common location [6]. Histologically, it is classified as tubular, trabecular, solid, and membranous. The trabecular pattern consists of interconnecting cords of basal cells and slightly larger cells (luminal) than basal cells. Duct-like structures with small lumens that are lined by luminal cells and basal cells are present. Outwardly located tumor cells may be focally palisaded [7]. Except for luminal and basal cells, the presence of neo- plastic myoepithelial cells in basal cell adenoma has been documented [8]. In our cases, nonluminal cells were found to be positive for S-100 protein and negative for vimentin and $\alpha$-SMA, thus supporting the evidence for neoplastic myoepithelial cells. Furthermore, in our cases we observed focal expression of S-100 protein in luminal cells. These findings are in accord with the report of Ogawa et al. [9], but not with other studies [10, 11]. Ogawa et al. [9] suggested that since S-100 protein is detected in intercalated ducts of normal salivary glands, the deriva- 
tion of basal cell adenoma may be from intercalated ducts. In the current study, the expression of cytokeratin 7 and high-molecular-weight cy tokeratins $(1,5,10,14)$ from the lining epithelium of the mucous retention cyst and tumor cells suggests that basal cell adenomas originate from the epithelium of excretory ducts. The basal cells of normal excretory ducts express KA-1 (cytokeratins 4, 5, 6) and cytokeratins 7 and 14, whereas the luminal cells express cytokeratins 7 and 17 [12].

In the present study, 2 cases of coexisting mucous retention cyst and basal cell adenoma arising from the lining epithelium of the cyst were documented. It is possible that the basal cell adenomas were developed from the lining epithelium of preexisting mucous retention cysts. In our cases, it was not possible to diagnose the preexistence of mucous retention cysts clinically or histologically. Sporadic case reports mention the development of salivary gland tumors in preexisting salivary duct cysts. Seifert [1] described 1 case of mucoepidermoid carcinoma arising from a preexisting salivary duct cyst of the parotid gland; Evans and Goldman [2] documented 1 case of basal cell adenoma arising from a lymphoepithelial cyst of the parotid gland; Krueger et al. [3] presented 2 cases of mucoepidermoid carcinoma arising from preexisting mucous retention and maxillary cysts; Mahler and Schell [4] reported 1 case of papillary cystadenoma arising from preexisting mucous retention cyst.

In our cases, it is possible that the mucous retention cysts were developed due to partial obstruction secondary to the presence of basal cell adenomas arising from excretory ducts. This possibility might be supported by the fact that basal cell adenoma most frequently occurs in the upper lip [6].

Since benign salivary gland tumors cannot be discriminated clinically from malignant tumors, an early excision of all cystic tumors resembling mucous retention cysts is mandatory [4].

\section{Conclusion}

The coexistence of mucous retention cyst and basal cell adenoma arising from the lining epithelium of the cyst is reported for first time in the literature.

\section{References}

1 Seifert G: Mucoepidermoid carcinoma in a salivary duct cyst of the parotid gland: contribution to the development of tumours in salivary gland cysts. Path Res Pract 1996; 192:1211-1217.

-2 Evans CHS, Goldman RL: Dermal analogue tumor arising in a lymphoepithelial cyst of the parotid gland. Arch Pathol Lab Med 1986;110:561-562.

3 Krueger K, Younce D, Najjar T, Seldin D, Koppelman E, Sansevere J: Does mucoepidermoid carcinoma arises from a cyst? Abstracts, Congr Int Assoc Oral Pathol, York, 1994, p 35.

4 Mahler V, Schell H: Papillary cystadenoma: a rare tumor of the minor salivary glands. Eur J Dermatol 1999;9:387-389.
5 Seifert G, Donath K, von Guberz C: Mucoceles of the minor salivary glands: extravasation mucoceles (mucous granuloma) and retention mucoceles (mucous retention cyst). HNO 1991;29:179-191.

6 Kratochvil FG: Canalicular adenoma and basal cell adenoma; in Ellis GL, Auclair PL, Gnepp DR (eds): Surgical Pathology of the Salivary Glands. Philadelphia, WB Saunders, 1991, pp 202-204.

7 Nagao K, Matsuzaki O, Saiga H, Sugano I, Shigematsu H, Kaneko T, Katoh T, Kitamura T: Histopathologic studies of basal cell adenoma of the parotid gland. Cancer 1982;50: 736-745.

8 Zarbo RJ, Prasad AR, Regezi JA, Gown AM, Savera AT: Salivary gland basal cell and canalicular adenomas: immunohistochemica demonstration of myoepithelial cell participation and morphogenetic considerations. Arch Pathol Lab Med 2000;124:401-405.
-9 Ogawa I, Nikai H, Takata T, Miyauchi M, Ito $\mathrm{H}$, Ijuhin N: The cellular composition of basal cell adenoma of the parotid gland: an immunohistochemical analysis. Oral Surg Oral Med Oral Pathol 1990;70:619-626.

10 Dardick I, Kahn HJ, van Nostrand AW, Baumal R: Salivary gland monomorphic adenoma: ultrastructural, immunoperoxidase, and histogenetic aspects. Am J Pathol 1984; 115:334-348.

-11 Kahn HJ, Baumal R, Marks A, Dardick I, van Nostrand AW: Myoepithelial cells in salivary gland tumors: an immunohistochemical study. Arch Pathol Lab Med 1985;109:190195.

12 Geiger S, Geiger B, Leitner O, Marshak G: Cytokeratin polypeptides expression in different epithelial elements of human salivary glands. Virchows Arch [A] 1987;410:403414. 